\title{
HALREV
}

Hasanuddin Law Review

\section{Aspek Hukum Pendaftaran Tanah Bekas Milik Asing sebagai Aset Pemerintah Daerah}

\author{
Legal Aspects of Land Registration of Foreign Owned Used \\ as a Local Government Asset
}

\author{
Sri Susyanti Nur \\ Bagian Hukum Keperdataan, Fakultas Hukum, Universitas Hasanuddin. \\ Jln. Perintis Kemerdekaan Km. 10, Tamalanrea, Makassar, 90245, Sulawesi Selatan, Indonesia. \\ Tel./Fax: +62-411-585188E-mail: srisusyanti@ymail.com
}

Submitted: Mar 24, 2015; Reviewed: Apr 4, 2015; Accepted: Apr 22, 2015

\begin{abstract}
Land as government aset can be derived by the former foreign-owned from land owned by Chinese and Dutch companies. Land as a local government aset is recognized after the registration of certified land. In the control, utilization and management by government agencies should be based on the Interior Minister Regulation Number 17 Year 2007 concerning technical guidance aset management to benefit the region. Results showed that the legal status of the land area in the city of Makassar asets from foreignowned Chinese and Dutch, there is already the status of land rights but there is also the status of state land has not been certified, this is due to the constraints of land titling asets belonging to the former Chinese foreign and Dutch regulatory aspects and aspects of administration
\end{abstract}

Keywords: Local Government; Land Aset; Certificate

\begin{abstract}
Abstrak: Tanah sebagai aset pemerintah dapat berasal dari tanah-tanah bekas milik asing yang berasal dari tanah-tanah milik Cina dan perusahaan-perusahaan Belanda. Tanah sebagai aset pemerintah daerah diakui setelah dilakukan pendaftaran tanah/bersertifikat. Dalam penguasaan, pemanfaatan, dan pengelolaannya oleh instansi pemerintah haruslah berdasarkan pada Peraturan Menteri Dalam Negeri Nomor 17 Tahun 2007 tentang Petunjuk teknis Pengelolaan Barang Milik Daerah (BMD) agar memberikan manfaat. Hasil penelitian menunjukan bahwa status hukum tanah aset daerah di kota Makassar yang berasal dari kepemilikan asing (Cina dan Belanda) ada yang telah berstatus Tanah Hak namun masih ada pula yang berstatus Tanah Negara/belum bersertifikat, disebabkan kendala pensertifikatan tanah aset daerah bekas milik asing Cina dan Belanda dari aspek peraturan perundang-undangan dan aspek administrasi.
\end{abstract}

Kata Kunci: Pemerintah Daerah; Tanah Aset; Sertifikat 


\section{PENDAHULUAN}

Pengertian Tanah Negara berbeda dengan pengertian Tanah aset pemerintah. Tanah aset pemerintah adalah tanah-tanah yang dikuasai oleh pemerintah baik pusat maupun daerah. Tanah aset pemerintah termasuk dalam golongan tanah hak dan merupakan aset negara yang penguasaan fisiknya ada pada instansi yang bersangkutan, sedangkan penguasaan secara yuridis berada pada Menteri Keuangan.

Tanah aset pemerintah sebagai salah satu objek pendaftaran tanah, penguasaan dan pengelolaannya diberikan kepada instansi pemerintah baik di pusat maupun di daerah, dengan Hak Pakai dan Hak Pengelolaan sesuai dengan Peraturan Menteri Negara Agraria Nomor 9 Tahun 1999 tentang Tata Cara Pemberian dan Pembatalan Hak Atas Tanah Negara dan Hak Pengelolaan. Selanjutnya, pada Pasal 49 ayat (1) Undang-Undang Nomor 1 Tahun 2004 tentang Perbendaharaan Negara dinyatakan bahwa barang milik Negara/Daerah berupa tanah yang dikuasai oleh Pemerintah Pusat/Daerah harus disertifikatkan atas nama Pemerintah RI/Pemerintah Daerah yang bersangkutan.

Hal ini dimaksudkan untuk menjamin kepastian hukum juga mengamankan aset-aset Pemerintah dan sebagai upaya untuk menertibkan penggunaan/pemanfaatan tanahnya. Sebagai bagian dari paket kebijakan Pengelolaan Perbendaharaan Negara, Pemerintah kemudian mengeluarkan Peraturan Pemerintah Nomor 38 tahun 2008 Juncto Peraturan Pemerintah (PP) Nomor 6 Tahun 2006 tentang Pengelolaan Barang Milik Negara/Daerah, sebagai peraturan pelaksanaan dari Undang-Undang Nomor 1
Tahun 2004 tentang Perbendaharaan Negara tersebut.

Pemerintah sebagai pemegang hak atas tanah, memiliki kewajiban yang sama dengan pemegang hak lainnya, seperti orang perorangan maupun badan hukum dalam pemanfaatan dan pengelolaan tanah sesuai dengan sifat tujuan peruntukannya. Kewajiban ini merupakan amanah Peraturan Pemerintah Nomor 38 Tahun 2008 Juncto Peraturan Pemerintah Nomor 6 Tahun 2006 tentang Pengelolaan Barang Milik Negara/ Daerah.

Pada ketentuan Pasal 33 disebutkan bahwa:

(1) Barang Milik Negara/Daerah berupa tanah harus disertifikatkan atas nama Pemerintah Republik Indonesia/Pemerintah Daerah yang bersangkutan

(2) Barang Milik Negara/Daerah berupa bangunan harus dilengkapi dengan bukti kepemilikan atas nama Pemerintah Republik Indonesia/Pemerintah Daerah yang bersangkutan

(3) Barang Milik Negara selain tanah dan/ atau bangunan harus dilengkapi dengan bukti kepemilikan atas nama pengguna bangunan

(4) Barang Milik Daerah selain tanah dan/ atau bangunan harus dilengkapi dengan bukti kepemilikan atas nama Pemerintah Daerah yang bersangkutan.

Dengan disertifikatkannya tanahtanah yang dikuasai pemerintah atas nama Pemerintah RI/Pemerintah Daerah yang bersangkutan, menurut penjelasan Pasal 33 Peraturan Pemerintah No. 38 Tahun 2008 Juncto Peraturan Pemerintah No. 6 Tahun 2006, adalah penerbitan sertifikat hak atas tanah milik pemerintah RI dilakukan secara langsung atas nama Pemerintah Provinsi/ Kabupaten/Kota. Selanjutnya, pengelolaan 
barang untuk tanah milik pemerintah pusat, dan Gubernur/Bupati/Walikota untuk tanah milik Pemerintah Daerah, akan ditertibkan surat penetapan status penggunaan tanah kepada masing-masing pengguna barang/ kuasa pengguna barang sebagai dasar pengguaan tanah tersebut. Hak atas tanah yang dapat diterbitkan berupa hak yang ditetapkan berdasarkan peraturan perundang-undangan yang berlaku.

Adapun tanah-tanah yang dapat dijadikan sebagai aset pemerintah antara lain tanah-tanah bekas milik asing/Cina atau Belanda yang dikuasai oleh Pemerintah RI antara tahun 1958-1966 berasal dari:

a) Aset bekas perkumpulan-perkumpulan Cina yang dinyatakan terlarang dan dibubarkan dengan Peraturan Penguasaan Perang Pusat Nomor Prt/032/ PERPU/1958 jo. Undang-Undang No. 50 Prp 1960.

b) Aset bekas milik perkumpulan-perkumpulan Belanda yang di Nasionalisasi dalam rangka aksi pengembalian Irian Barat berdasarkan UndangUndang No. 86 Tahun 1958 tentang Nasionalisasi Perusahaan-Perusahaan Milik Belanda

c) Aset bekas milik perkumpulan-perkumpulan aliran kepercayaan asing yang dinyatakan terlarang dan dibubarkan berdasarkan Undang-Undang No. 2 Pnps Tahun 1962.

d) Aset bekas milik perkumpulan-perkumpulan Cina yang menjadi sasaran aksi massa tahun 1965/1966 dalam rangka G.30S/PKI.

e) Aset bekas milik perkumpulan-perkumpulan ekslusif rasial Cina yang secara yuridis formal sudah tidak ada lagi.
Berdasarkan uraian tersebut di atas, maka perumusan masalah pada tulisan ini sebagai berikut: Pertama, Status hukum tanah-tanah bekas milik asing/Cina dan Belanda yang menjadi aset pemerintah daerah Kota Makassar berdasarkan UndangUndang Nomor 86 Tahun 1956 tentang Nasionalisasi Perusahan-Perusahaan Bekas Belanda, dan Peraturan Menteri Keuangan No. 154/PMK.06/2011 Jo. Peraturan Menteri Keuangan No.188/PK.06/2008 tentang Penyelesaian Aset Bekas Milik Asing/Cina; Kedua, Sertifikasi Aset Berupa Tanah di Kota Makassar; Ketiga, Kendala yang dihadapi oleh Pemerintah Kota Makassar dalam upaya pensertifikatan aset tanah bekas milik asing/Cina dan Belanda.

\section{METODE}

Penelitian ini dilaksanakan di Kota Makassar, dengan mengambil data dan informasi di Kantor Walikota Makassar, Kantor Badan Pertanahan Kota Makassar, dan Kantor Pengelolaan Kekayaan Negara Wilayah XV Direktorat Jenderal Kekayaan Negara (DJKN) Makassar.

Metode pendekatan yang digunakan dalam penelitian ini adalah dengan pendekatan yuridis-sosiologis, yaitu suatu penelitian yang didasarkan pada suatu ketentuan hukum (peraturan yang berlaku) dengan kenyataan/ fenomena yang terjadi di lapangan serta dalam praktiknya sesuai dengan kejadian sebenarnya. Jenis penelitian menggunakan metode diskriptif, yakni hanya memaparkan secara lengkap, rinci dan sistematis.

Sumber data primer dalam tulisan ini adalah data yang langsung diperoleh di lapangan berdasarkan wawancara langsung 
dengan pihak yang berwenang. Dalam hal ini: Kepala Subseksi Pengaturan Tanah Pemerintah Kantor Badan Pertanahan Kota Makassar, Kepala Sub bagian Inventarisasi Aset, Kepala Sub Bagian Dokumen dan Informasi Hukum Kantor Walikota Makassar, dan Kepala Bidang Pengelolaan Kekayaan Negara Direktorat Jenderal Kekayaan Negara Wilayah XV Makassar. Adapun sumber data sekunder, yaitu data yang diperoleh secara tidak langsung, antara lain mencakup dokumen-dokumen resmi, buku-buku, hasilhasil penelitian yang berwujud laporan, dan sebagainya.

Hasil penelitian akan disajikan secara deskriptif, mengenai status hak atas tanah aset pemerintah kota Makassar, sertifikasi aset berupa tanah di Kota Makassar, dan kendala umum yang dihadapi Pemerintah Kota Makassar dalam upaya sertifikasi tanah aset daerah.

\section{ANALISIS DAN PEMBAHASAN}

Status Hukum Tanah Bekas Milik Asing sebagai Aset Pemerintah Kota Makassar

Status tanah bekas milik asing yang menjadi aset dalam pembahasan penelitian ini, terdiri dari 2 (dua), yakni: Pertama, tanah bekas milik asing/Cina yang menjadi Tanah Hak dan Tanah Negara. Menjadi "Tanah Hak" ketika tanah bekas milik asing yang telah disertifikatkan sesuai dengan Peraturan Pemerintah Nomor 24 Tahun 1997 tentang Pendaftaran Tanah, selanjutnya disebut Tanah Negara untuk tanah-tanah bekas milik asing yang belum ditegaskan status hukumnya sebagai tanah hak (belum bersertifikat); Kedua, tanah bekas milik perusahaan-perusahaan Belanda yang menjadi aset peme- rintah daerah berdasarkan Undang-Undang Nomor 86 Tahun 1958 tentang Nasionalisasi Perusahaan-Perusahaan Milik Belanda dan Undang-Undang Nomor 3 Tahun 1966 tentang Penguasaan Benda-Benda Tetap Milik Perorangan Warga Negara Belanda.

Status hukum tanah aset pemerintah daerah yang dimaksudkan adalah hak atas tanah berupa Hak Pakai atas tanah negara dan/atau Hak Pengelolaan yang dilimpahkan kepada instansi pemerintah dalam hal ini Pemerintah Daerah Kota Makassar.

\section{Dalam Pasal 33 ayat (3) UUD NRI} 1945 dinyatakan bahwa "bumi, air dan kekayaan alam yang terkandung di dalamnya dikuasai oleh negara dan dipergunakan untuk sebesar-besarnya kemakmuran rakyat". Pasal ini menjadi dasar ketentuan berlakunya Hak Menguasai Negara dan hak negara untuk mengatur dan menyelenggarakan peruntukan, penggunaan, persediaan dan pemeliharaan bumi, air dan ruang angkasa termasuk kekayaan alam yang terkandung di dalamnya.

Penguasaan Negara atas tanah diseluruh wilayah Republik Indonesia bersumber dari Hak Bangsa Indonesia yang meliputi kewenangan Negara dalam Hak Menguasai Negara (HMN) sebagaimana yang tercantum dalam Pasal 2 ayat (2) UUPA, yaitu: ${ }^{1}$

a. Mengatur dan menyelenggarakan peruntukan, penggunaan dan persediaan dan pemeliharaan bumi, air dan ruang angkasa tersebut;

b. Menentukan dan mengatur hubunganhubungan hukum antara orang-orang den-

1 Arie Sukanti Hutagalung dan Markus Gunawan. (2008). Kewenangan Pemerintah di Bidang Pertanahan. Jakarta: Rajawali Pers, hlm. 24 
gan bumi, air dan ruang angkasa

c. Menentukan dan mengatur hubunganhubungan hukum antara orang-orang dan perbuatan-perbuatan hukum yang mengenai bumi, air dan ruang angkasa

d. Hak-hak atas tanah tersebut memberi wewenang untuk mempergunakan tanah yang bersangkutan sekedar diperlukan untuk kepentingan yang langsung berhubungan dengan penggunaan tanah itu dalam batasan-batasan menurut ketentuan perundang-undangan.

Dari ketentuan dalam UUPA, dapat dilihat negara memberikan hak-hak atas tanah kepada perorangan atau badan hukum (subjek hak) bahkan menjamin, mengakui, melindungi hak-hak tersebut untuk dimanfaatkan dalam rangka mensejahterakan kehidupannya dan tidak boleh diambil secara sewenang-wenang oleh siapapun.

Berdasarkan Peraturan Menteri Negara Agraria/Kepala Badan Pertanahan Nasional Nomor 3 Tahun 1997 tentang Ketentuan Pelaksanaan Peraturan Pemerintah Nomor 24 tahun 1997 tentang Pendaftaran Tanah, disebutkan alas hak yang diberi istilah data yuridis yakni keterangan mengenai status hukum, bidang tanah, pemegang haknya dan pihak lain serta bahan-bahan lain yang membebaninya. Secara perdata, dengan adanya hubungan antara yang mempunyai tanah dengan tanahnya yang dibuktikan dengan penguasaan fisik secara nyata di lapangan atau ada alas hak berupa data yuridis berarti telah dilandasi dengan suatu hak, tanah tersebut sudah berada dalam penguasaannya atau menjadi miliknya.

Dasar penguasaan atau alas hak untuk tanah menurut UUPA adalah bersifat derivative, artinya berasal dari ketentuan perundang-undangan dan hak-hak yang ada sebelumnya seperti hak-hak adat dan hakhak barat. ${ }^{2}$ Dengan catatan dilakukan penyesuaian dengan ketentuan yang baru dalam hukum agraria dikenal dengan istilah "konversi”. Maksud dari konversi hak atas tanah tersebut adalah perubahan hak atas tanah menjadi hak baru sebagaimana yang diatur dalam UUPA. Diartikan pula yakni bagaimana pengaturan dari hak-hak atas tanah yang ada sebelum berlakunya UUPA untuk masuk dalam sistem UUPA. ${ }^{3}$

Hal ini menandakan bahwa setelah berlakunya UUPA, maka semua hak-hak Barat yang belum dibatalkan sesuai ketentuan sebagaimana tersebut di atas, dan masih berlaku tidak serta merta hapus dan tetap diakui, akan tetapi untuk dapat menjadi hak atas tanah sesuai dengan sistem yang diatur oleh UUPA, harus terlebih dahulu dikonversi menurut dan sesuai dengan ketentuan-ketentuan konversi dan aturan pelaksanaannya.

Dalam pelaksanaan konversi tersebut ada beberapa prinsip yang mendasarinya yaitu:

\section{Prinsip nasionalitas}

Prinsip Nasionalitas termuat dalam Pasal 1 ayat (1) UUPA, bahwa "Seluruh wilayah Indonesia adalah kesatuan tanah air dari seluruh rakyat Indonesia yang bersatu sebagai Bangsa Indonesia."

Dalam Pasal 19 jo. Pasal 26 ayat (2) UUPA, secara jelas menyebutkan hanya warga Negara Indonesia saja yang boleh mempunyai hubungan yang sepenuhnya

2 A.P. Parlindungan. (1993). Komentar Atas Undang-Undang Penataan Ruang. Bandung: Penerbit Mandar Maju, hlm. 3

3 Ibid. hlm. 94 
dengan bumi, air dan ruang angkasa. Kedua pasal tersebut menyatakan bahwa hanya Bangsa Indonesia yang dapat memiliki hak atas tanah dan hak milik tidak dapat dimiliki oleh orang asing. ${ }^{4}$ Badan-badan hukum Indonesia juga memiliki hak-hak atas tanah, namun terbatas hanya badan-badan hukum yang ditunjuk oleh Peraturan Pemerintah Nomor 38 Tahun 1963 tentang Badan-badan Hukum yang Dapat Mempunyai Hak Milik.

\section{Pengakuan hak-hak tanah terdahulu}

Konversi hak atas tanah berkaitan dengan jenis-jenis hak atas tanah yang ada sebelum dan setelah lahirnya UUPA tahun 1960. Pemerintah Indonesia setelah kemerdekaan tetap mengakuinya hak-hak atas tanah sebelum berlakunya UUPA, yaitu hak-hak yang pernah tunduk kepada Hukum Barat maupun kepada Hukum Adat yang kesemuanya didaftarkan melalui ketentuan Konversi dalam UUPA dan Peraturan Menteri Pertanian dan Agraria Nomor 2 Tahun 1962 tentang Penegasan Konversi dan Pendaftaran Bekas Hakhak Indonesia Atas Tanah.

\section{Penyesuaian kepada ketentuan konversi}

Dasar hukum ketentuan konversi hak atas tanah terdapat di bagian kedua UUPA, yaitu Pasal I sampai dengan Pasal VIII. Secara garis besar dibagi atas: Konversi hak atas tanah berasal dari tanah hak Barat; Konversi hak atas tanah berasal dari tanah bekas Hak Indonesia; dan Konversi hak atas tanah berasal dari tanah bekas swapraja.

\section{Status quo hak-hak tanah terdahulu}

Menurut ketentuan dalam UUPA Diktum Kedua Pasal I, III dan V hak-hak atas tanah

\footnotetext{
4 Kartini Muljadi. (2008). Hak-Hak Atas Tanah. Jakarta: Kencana, hlm. 83
}

asal konversi Hak Barat akan berakhir masa berlakunya selambat-lambatnya tanggal 24 September 1980 dan karenanya sejak saat itu menjadi tanah yang langsung dikuasai oleh negara.

Untuk mengatur akibat-akibat hukum dari ketentuan tersebut dan menentukan hubungan hukum serta penggunaan peruntukannya lebih lanjut dari tanah tersebut, telah dikeluarkan Keputusan Presiden No. 32 Tahun 1979 tentang Pokok-pokok Kebijaksanaan dalam Rangka Pemberian Hak Baru Atas Tanah Asal Konversi Hak Barat, dan sebagai tindak lanjut atas Keputusan Presiden tersebut telah dikeluarkan Peraturan Menteri Dalam Negeri No. 3 Tahun 1979.

Maksud dari pada kedua peraturan tersebut kecuali menegaskan status tanah sebagai tanah yang langsung dikuasai oleh negara, pada saat berakhirnya hak atas tanah asal konversi hak Barat, juga dimaksudkan untuk mengatur kebijaksanaan menyeluruh dalam rangka penataan kembali penggunaan, penguasaan dan pemilikan tanah.

Pokok kebijaksanaan dalam Keputusan Presiden No. 32 Tahun 1979 adalah penegasan kembali tentang berakhirnya hak atas tanah asal Konversi Hak-hak Barat (yang dikonversi menjadi Hak Guna Usaha, Hak Guna Bangunan dan Hak Pakai) pada tanggal 24 September 1980, yang juga merupakan prinsip yang telah digariskan di dalam UUPA, dengan maksud untuk dapat benarbenar mengakhiri berlakunya sisa hak-hak Barat atas tanah di Indonesia dengan segala sifat-sifatnya yang tidak sesuai dengan Pancasila dan UUD NRI 1945. Oleh karena itu, hak atas tanah asal Konversi Hak Barat itu tidak akan diperpanjang lagi. Tanah-tanah 
asal Konversi Hak-hak Barat dimaksud sejak 24 September 1980 statusnya menjadi tanah yang dikuasai negara, dan selanjutnya oleh negara akan diatur kembali penggunaan, penguasaan dan pemilikan tanah melalui pemberian hak baru.

Sesuai dengan prinsip nasionalitas yang dianut dalam UUPA, ketentuan konversi terhadap orang asing pada tanggal 24 September 1960 yang memiliki tanah berdasarkan KUH Perdata dalam waktu satu tahun harus sudah memindahkan haknya kepada warga negara Indonesia dan jika lalai melakukannya maka tanahnya menjadi tanah yang kembali dikuasai oleh negara. Hal ini diatur dalam ketentuan Konversi Pasal I, III, IV, V dan VI UUPA.

\section{Tanah bekas milik asing Belanda}

Perolehan tanah milik asing Belanda berkaitan erat dengan Staatsblaad 118 Tahun 1870 tentang penerapan asas domeinverklaring pada masa kolonial. Domeinverklaring mengatur bahwa setiap tanah yang tidak dapat dibuktikan secara administratif merupakan milik negara.

Hal ini menyebabkan Daerah Swatantra pada saat itu menjadi pemilik tanah dan tanah-tanah masyarakat yang tidak bisa dibuktikan secara administratif menjadi milik pemerintah termasuk pemerintah kolonial yang tersebar di berbagai daerah. Penguasaan dan Pengelolaan Tanah Aset Daerah terjadi sejak zaman Hindia Belanda dengan diberlakukannya Staatsblaad 1911 Nomor 110 sampai berlakunya UUD $1945 .^{5}$

5 Supriyadi dan Subadi. (2011). "Tanah Aset Daerah dalam Perspektif Konstitusi”. Jurnal Konstitusi, FKKP-FH Universitas Merdeka Madiun, 1(1): 11-27
Pemerintah Daerah sebagai pemilik atas tanah dengan istilah Gemeente Grond. Tanah yang dikuasai Gemeente tersebut berupa tanah negara bebas "vrijlandsdomein" (tanah-tanah yang tidak ada hak pribumi diatasnya termasuk yang digunakan untuk kegiatan pemerintahan) dan tanah negara tidak bebas "onvrijlandsdomein" (ada hak-hak pribumi di atasnya).

Substansi Staatsblaad Nomor 110 Tahun 1911 tampaknya diadopsi dalam Peraturan Pemerintah Nomor 8 Tahun 1953 tentang Penguasaan Tanah-Tanah Negara. Dalam Peraturan Pemerintah tersebut dinyatakan bahwa tanah-tanah negara yang telah diserahkan kepada suatu kementerian, jawatan atau daerah swatantra sebelum berlakunya Peraturan Pemerintah Nomor 8 tahun 1953 maka penguasaannya berada pada kementerian, jawatan atau daerah swatantra tersebut, kemudian oleh Peraturan Menteri Agraria Nomor 9 Tahun 1965 tentang Pelaksanaan Konversi Hak Penguasaan Atas Tanah Negara, maka hak penguasaan tanah ini dikonversi menjadi Hak Pengelolaan. ${ }^{6} \mathrm{Hal}$ inilah yang mendasari penguasaan tanahtanah negara oleh Pemerintah Daerah Kota Makassar.

Diadopsinya substansi staatsblaad tersebut menyebabkan Peraturan Pemerintah ini masih menetapkan pemerintah sebagai pemegang kekuasaan yuridis atas tanahtanah bekas gemeente Makassar termasuk tanah negara tidak bebas. Dalam Peraturan Pemerintah ini, kekuasaan negara atas tanah negara tidak bebas diatur, ketentuan pada

6 Urip Santoso. (2010). Pendaftaran dan Peralihan Hak Atas Tanah. Jakarta: Kencana Prenada Media Group, hlm. 113 
Pasal 12 menyatakan bahwa Kepada Daerah Swatantra dapat diberikan penguasaan atas tanah negara dengan tujuan diberikan kepada pihak ketiga menurut ketentuan Menteri Dalam Negeri.

Implementasi dari ketentuan Pasal 12 ini adalah Menteri Dalam Negeri telah memutuskan tanah-tanah dan bangunan yang telah dikuasai oleh masyarakat sejak pemerintahan Kolonial agar dilepaskan kepada masyarakat, dengan terlebih dahulu mengadakan penelitian tentang penguasaan tanah-tanah bekas Belanda oleh masyarakat. Kegiatan penelitian diatur pula dalam Pasal 13 PP No. 8 Tahun 1953 tersebut yang menyatakan bahwa Daerah Swatantra yang menyatakan laporan lengkap tentang keadaan dan penggunaan tanah tersebut kepada Menteri Dalam Negeri.

Berdasarkan hasil penelitian oleh Pemerintah Daerah Tingkat II Ujung Pandang (Kota Makassar) maka dikeluarkanlah dua Surat Keputusan Mendagri tentang pelepasan hak atas tanah di Daerah Tingkat II Ujung Pandang (Kota Makassar): (1) Surat Keputusan Menteri Dalam Negeri Nomor 593.3 192 tentang Pengesahan dan Pelepasan Hak Atas Tanah yang dikuasai Oleh Pemerintah Kota Madya Daerah Tingkat II Ujung Pandang; (2) Surat Keputusan Mendagri Nomor 593.3-326 tentang Pengesahan Pelepasan Hak Atas Tanah yang Dikuasai/Dimanfaatkan oleh Pemerintah Kota Madya Daerah Tingkat II Ujung Pandang Kepada Anggota Masyarakat yang Telah Mendudukinya dengan Pembayaran Ganti Rugi.

Salah satu pertimbangan dalam Surat keputusan tersebut di atas adalah pernyataan persil tanah bangunan tersebut telah dipergu- nakan oleh masyarakat/penduduk setempat sebagai perumahan dengan status menyewa dari Pemerintah Kota Makassar. Berdasarkan SK Mendagri Nomor 593-3-326 ditetapkan harga sewa yang harus dibayarkan berbeda-beda mulai dari $12.500 / \mathrm{m}^{2}$ hingga 7 . $500 / \mathrm{m}^{2}$. Jika telah mencapai jumlah yang disyaratkan maka hak atas tanah dapat ditingkatkan menjadi Hak Milik. Pembayaran Sewa sebagai pemasukan kepada Anggaran Pendapatan dan Belanja Daerah.

Berkaitan dengan jumlah tanah yang telah ditingkatkan statusnya berdasarkan data Dokumentasi dan Informasi Hukum di Pemkot Makassar, bahwa masih terdapat tanah-tanah yang menurut Surat Keputusan Mendagri Nomor 593.3-326 tersebut yang belum ditingkatkan statusnya oleh yang berhak sehingga masih tercatat sebagai aset daerah. Artinya, kekuasaan yuridis atas tanah tersebut masih terdapat pada Pemerintah Daerah Kota Makassar walaupun secara fisik dikuasai oleh masyarakat. Kategorisasi tanah-tanah yang belum ditingkatkan statusnya tersebut menjadi aset daerah juga sesuai dengan Lampiran II angka 20 dan 21 Peraturan Pemerintah Nomor 71 Tahun 2010 tentang Standar Akuntansi Pemerintahan (SAP) karena masih memiliki potensi ekonomi pada masa yang akan datang berupa penerimaan dalam Anggaran Pendapatan dan Belanja Daerah.

Pelaksanaan Undang-Undang Nomor 86 tahun 1958 tentang Nasionalisasi Perusahan-Perusahan Milik Belanda, selanjutnya dikeluarkan Peraturan Pemerintah Nomor 2 Tahun 1959 (LN. 1959 No. 5) tentang Pokok-Pokok Pelaksanaan Undang-undang Nasionalisasi Perusahaan Belanda. Pada 
Pasal 1 Peraturan Pemerintah Nomor 2 Tahun 1959 menyatakan bahwa perusahaan milik Belanda yang dikenakan Nasionalisasi adalah:

a) Perusahaan-perusahaan yang untuk seluruhnya atau sebahagian merupakan milik perseorangan warganegara Belanda dan bertempat kedudukan dalam wilayah RI;

b) Perusahaan milik suatu badan hukum yang seluruhnya atau sebahagian modal perseroannya atau modal pendiriannya berasal dari perseorangan warganegara Belanda dan badan hukum itu bertempat kedudukan dalam wilayah RI;

c) Perusahaan-perusahaan yang letaknya dalam wilayah RI dan untuk seluruhnya atau sebahagian merupakan milik perseorangan warganegara Belanda yang bertempat kediaman di luar wilayah RI;

d) Perusahan yang letaknya dalam wilayah RI dan merupakan milik sesuatu badan hukum yang bertempat kedudukan di wilayah Negara Kerajaan Belanda.

Proses Nasionalisasi dilakukan Pemerintah RI dengan cara memberi ganti kerugian kepada pemilik perusahaan-perusahaan Belanda tersebut, sehingga harta kekayaan perusahaan milik Belanda yang dikenakan nasionalisasi tersebut menjadi milik Negara. Hak milik tanah perusahaan Belanda menjadi hapus karena hukum dan tanahnya menjadi tanah Negara. Hal ini ditegaskan oleh Keputusan Menteri Pertanian dan Agraria No.SK.8/Ka/1963, tanggal 28 Februari 1963 tentang Pemberian Hak Atas Tanah Bekas Perusahaan-Perusahaan Milik Belanda kepada Perusahaan-perusahaan Negara dan Bank-Bank Negara.

Tanah-tanah perusahaan milik Belanda yang menjadi tanah Negara diperoleh melalui beberapa cara:

a) Pembelian tanah untuk Pemerintah melalui Bijblad 11372 jo. 12746; b) Pembebasan tanah menurut Peraturan Menteri Dalam Negeri Nomor 15 tahun 1975;

c) Pengadaan tanah menurut Peraturan Menteri Dalam Negeri Nomor 2 tahun 1985;

d) Pengadaan tanah menurut Keputusan Presiden Nomor 55 Tahun 1993 jo. Peraturan Menteri Negara Agraria/Kepala Badan Pertanahan Nasional Nomor 1 tahun 1994;

e) Pencabutan hak menurut Undang-undang Nomor 20 tahun 1961;

f) Pelepasan hak secara cuma-cuma oleh pemiliknya kepada Pemerintah (secara umum dikenal sebagai penyerahan tanah untuk Pemerintah);

Pada tahun 1966, semua aset perusahaan milik Belanda yang terkena tindakan penguasaan dan nasionalisasi telah diperhitungkan dan dibayar lunas kepada Pemerintah Kerajaan Belanda. Sejak saat itu semua aset bekas milik Belanda telah menjadi milik Negara Republik Indonesia. Tanah-tanah perusahaan milik Belanda yang menjadi tanah Negara dan berada di bawah penguasaan instansi Pemerintah dapat digunakan untuk kepentingan pelaksanaan tugasnya maupun dapat diberikan kepada pihak lain.

Hal ini sejalan dengan Surat Kepala Badan Pertanahan Nasional tertanggal 9 Januari 1991 Nomor 530.22-134 mengenai Penertiban Tanah Asal Konversi Hak Barat yang dikuasai/dimiliki Instansi Pemerintah/ Badan-badan Negara dan Badan Usaha Milik Negara, yang ditujukan kepada: (1) Kepala Lembaga Tertinggi/Tinggi Negara; (2) Para Menteri Kabinet Pembangunan V; (3) Para Ketua Lembaga Pemerintah Non Departemen. Surat Kepala Badan Pertanahan Nasional ini menegaskan bahwa apabila di atas tanah berdiri bangunan milik instansi 
pemerintah/departemen, maka tanah akan diberikan kepada instansi pemerintah/departemen tersebut setelah mendapat persetujuan Menteri Keuangan.

Berdasarkan ketentuan yang ada, maka Pemerintah Kota Makassar menguasai tanah-tanah Negara bekas perusahaanperusahaan milik Belanda yang terletak di kota Makassar untuk menunjang kegiatan operasionalnya. Tanah-tanah tersebut adalah tanah bekas Naamloose Venoschaap (N.V.) Maskapai Kapal Selebes Selatan. Tanah tersebut di Nasionalisasi berdasarkan Keputusan Menteri Pertanian dan Agraria No SK.8/Ka/1963 tanggal 28 Februari 1963 tentang Pemberian Hak Atas Tanah Bekas Milik Perusahaan-Perusahaan Belanda dengan cara memberikan ganti rugi kepada pemilik-pemilik perusahaan Belanda tersebut, selanjutnya Pemerintah Republik Indonesia menyerahkan penguasaan atas tanah tersebut kepada Pemerintah Ujung Pandang (Kota Makassar) pada tahun 1966 untuk menunjang kegiatan operasional pemerintah daerah.

\section{Tanah Bekas Milik Asing/Cina}

Selain tanah-tanah aset daerah yang berasal dari tanah bekas milik Belanda, terdapat pula tanah-tanah yang berasal dari tanah bekas milik Asing/Cina. Terkait dengan penguasaan tanah bekas milik asing/Cina oleh Pemerintah Republik Indonesia dilakukan antara tahun 1958 sampai dengan tahun 1966. Objek tanah tersebut tertuang pula dalam Pasal 4 Peraturan Menteri Keuangan No. 188/PMK.06/2008 tentang Penyelesaian Tanah Bekas Milik Asing:

a. Aset bekas milik perkumpulan-perkumpulan Cina yang dinyatakan terlarang dan dibubarkan dengan Peraturan Penguasa Perang Pusat Nomor Prt/032/PEPERPU/1958 juncto Undang-Undang Nomor 50 Prp 1960. Peraturan penguasa perang pusat tersebut menyatakan melarang dan membubarkan semua perkumpulan/ organisasi/perusahaan yang didirikan oleh dan untuk warga Negara asing yang pemerintahnya tidak ada hubungan diplomatik dengan Pemerintah Republik Indonesia atau yang hubungan diplomatiknya sedang diputuskan. Pihak-pihak yang terkena adalah perkumpulan Cina yang didirikan oleh Warganegara Cina Taiwan. Peraturan Perang Pusat tersebut telah diubah menjadi Undang-Undang Nomor 56 Prp 1960.

b. Aset bekas milik perkumpulan-perkumpulan aliran kepercayaan asing yang dinyatakan terlarang dan dibubarkan berdasarkan Undang-Undang Nomor 2 Pnps tahun 1962 tentang Larangan Adanya organisasi yang tidak sesuai dengan kepribadian Indonesia, yang dalam pelaksanaannya dengan Keputusan Presiden Nomor 364 tahun 1962 telah dinyatakan bubar dan terlarang atas tujuh buah organisasi. Sesuai dengan ketentuan tersebut, sepanjang aset itu milik perkumpulan atau organisasi, aset tersebut menjadi milik Negara.

c. Aset bekas milik perkumpulan-perkumpulan Cina yang menjadi sasaran aksi massa/kesatuan aksi tahun 1965/1966 dalam rangka keterlibatan RRC dalam pemberontakan G30S/PKI, selanjutnya tanah dan bangunan-bangunan itu dikuasai oleh Pemerintah berdasarkan Instruksi Kepala Staf Komando Tertinggi Nomor T-403/G-5/1966, yang memerintahkan para penguasa pelaksana Dwikora Daerah (PEPELRADA) untuk menguasai tanah dan bangunan dan mendayagunakannya untuk kepentingan nasional.

d. Aset bekas milik perkumpulan-perkumpulan eksklusif rasial Cina yang secara yuridis formal sudah tidak ada lagi, hal ini juga berkaitan dengan Surat Menteri Keuangan S-394/MK.03/1989 tanggal 12 April 1989 tentang Gedung dan Tanah 
Bekas Sekolah/Cina. Pedoman umum tentang prosedur teknis memuat prosedur pemantapan status hukum aset (tanah/ bangunan) bekas sekolah asing, pengajuan permohonan untuk memperoleh hak atas tanah instansi pemerintah dengan proses penyelesaiannya, mengajukan permohonan untuk memeriksa/meneliti kondisi bangunan bekas sekolah asing, serta penaksiran harga tanah dan bangunan bekas sekolah asing.

Peraturan Menteri Keuangan Nomor 188/PMK.06/2008 tentang Penyelesaian Aset Bekas Milik Asing/Cina, sebagai peraturan yang membahas penyelesaian aset bekas milik asing/Cina, yaitu aset tanah dan bangunan milik asing/Cina yang telah dikuasai oleh pemerintah Indonesia selama kurun waktu sekitar 40 tahun.

Berdasarkan data berupa Daftar bekas milik asing/Cina di DJKN (khususnya yang alternatif penyelesaiannya disertifikatkan atas nama Pemerintah Daerah) maka dapat dinyatakan bahwa tanah-tanah aset daerah bekas milik Cina tersebut merupakan sekolah Cina yang diambil alih berdasarkan Surat Menteri Keuangan S-394/MK.03/1989 tanggal 12 April 1989 tentang Gedung dan Tanah Bekas Sekolah Cina. Adapun tanah-tanah bekas milik asing/Cina yang hingga saat ini masih berstatus tanah negara walaupun secara fisik dikuasai oleh Pemerintah Daerah Kota Makassar (dikategorikan sebagai aset daerah Kota Makassar).

Menurut Kepala Bidang Pengelolaan Kekayaan Negara DJKN Wilayah XV Makassar, mekanisme penyelesaian tanah bekas milik cina yang dikuasai secara fisik oleh pihak ketiga dalam kurun waktu yang lama, maka hak atas tanah diberikan kepada pihak ketiga paling singkat telah menguasai tanah bekas milik asing/Cina selama lima tahun. Pihak ketiga dalam petunjuk penyelesaian tersebut berupa Badan Hukum maupun Perorangan.

\section{Sertifikasi Tanah Aset Pemerintah Kota} Makassar

Aset adalah barang yang dalam pengertian hukum disebut benda, yang terdiri dari benda tidak bergerak dan benda bergerak. Tanah sebagai salah satu aset adalah berupa aset berwujud dan tidak bergerak. Selanjutnya Aset Negera adalah barang milik/kekayaan Negara yang meliputi barang tidak bergerak (tanah dan/atau bangunan) dan bergerak (investasi). ${ }^{7}$

Adapun tanah sebagai aset daerah adalah tanah-tanah dalam penguasaan daerah dengan syarat: ${ }^{8}$

a. Diperoleh dengan maksud untuk dipakai dalam kegiatan operasional pemerintah daerah dan dalam kondisi siap pakai.

b. Adanya bukti penguasaan secara hukum, misalnya Sertifikat Hak Pakai atau Hak Pengelolaan atas nama Daerah; atau ada bukti pembayaran dan penguasaan Sertifikat tanah atas nama pemilik sebelumnya

c. Dapat diukur dengan satuan uang

Walaupun demikian persyaratan tersebut diatas, tidak dengan serta merta menjadikan tanah-tanah dalam penguasaan daerah menjadi Aset Daerah. Hal ini sebagaimana ditegaskan oleh Surat Kepala Badan Pertanahan Nasional tanggal 6 Desember 1990 Nomor 5000-5569-DIII, tentang Penerbitan Sertifikat Tanah-tanah Instansi Pemerintah,

7 Doli D. Siregar. (2004). Manajemen Aset. Jakarta: PT Gramedia Pustaka Utama, hlm.178-179

8 Supriyadi. (2010). Aspek Hukum Tanah Aset Daerah. Jakarta: PT. Prestasi Pustakaraya, hlm. 255 
dan Surat Kepala Badan Pertanahan Nasional tanggal 4 Mei 1992 Nomor 500-1255 mengenai petunjuk pelaksanaan tentang Tata Cara Pengurusan Hak dan Penyelesaian Sertifikat tanah yang dikuasai Instansi Pemerintah.

Kepala Badan Pertanahan Nasional dalam menetapkan aset pemerintah, didasarkan pada: 1) Tanah-tanah bukan tanah pihak lain yang telah dikuasai secara fisik oleh Instansi Pemerintah; 2) Tanah tersebut dikelola dan dipelihara/dirawat dengan dana dari Instansi Pemerintah; 3) Tanah-tanah tersebut telah terdaftar dalam daftar Inventaris Instansi Pemerintah yang bersangkutan; 4) Tanah secara fisik dikuasai atau digunakan atau dimanfaatkan oleh pihak lain berdasarkan hubungan hukum yang dibuat antara pihak lain dengan instansi Pemerintah yang dimaksud; 5) Tanah tersebut angka $1 \mathrm{~s} / \mathrm{d} 3$ baik yang sudah ada sertifikatnya maupun yang belum ada sertifikatnya.

Selanjutnya, tanah-tanah oleh/dan dapat dikatakan sebagai aset pemerintah apabila berasal dari: 1) Tanah Negara, jika berdasarkan Staatblad tahun 1911 Nomor 110 tentang "Penguasaan Benda-benda tidak bergerak, gedung-gedung dan lain-lain Bangunan milik Negara" kemudian diatur kembali dengan Peraturan Pemerintah Nomor 8 Tahun 1953 tentang "Penguasaan tanah tanah Negara", menguasai tanah dimaksudkan sejak zaman Pemerintah Hindia Belanda sampai saat berlakunya Peraturan ini, maka tanah tersebut berstatus dalam penguasaan (in beheer) instansi Pemerintah yang bersangkutan; 2) Apabila setelah berlakunya Peraturan Pemerintah Nomor 8 tahun 1953 Tanah Negara dikuasai oleh Instansi Pemer- intah berdasarkan Surat Keputusan Pemberian Hak yang diterbitkan oleh Peraturan Menteri Dalam Negeri. ${ }^{9}$

Pada saat Indonesia merdeka, Indonesia tetap mengadopsi substansi Staatsblaad 1911 Nomor 110 dalam Peraturan Pemerintah Nomor 8 tahun 1953 tentang Penguasaan Tanah-Tanah Negara, hal ini tercantum dalam Pasal 2 yang menunjuk Penjelasan Umum angka 7 yang menjelaskan bahwa peraturan pada zaman Hindia Belanda dipakai sebagai dasar penyerahan penguasaan atas tanah-tanah Negara kepada daerah Swatantra adalah Staatsblaad 1911 Nomor 110 tentang Penguasaan Benda-Benda Tidak Bergerak. Mengenai penguasaan tanah Negara oleh instansi Pemerintah atau daerah setelah berlakunya Peraturan Pemerintah Nomor 8 tahun 1953, selanjutnya baru dapat menjadi aset apabila dikuasai oleh Pemerintah atau Daerah berdasarkan Surat Keputusan Pemberian Hak yang diterbitkan oleh Peraturan Kepala Badan Pertanahan Nasional Nomor 9 tahun 1999 tentang Pemberian Hak Atas Tanah Negara dan Hak Pengelolaan Serta Pembatalan Hak Atas Tanah. Apabila tanah-tanah Negara yang diklaim dalam penguasaan instansi Pemerintah atau Daerah tersebut belum diterbitkan Surat Keputusan Pemberian Hak atas nama instansi Pemerintah atau Daerah, maka tanah-tanah tersebut belum dan bukan menjadi aset Instansi Pemerintah atau Daerah.

Pentingnya pendaftaran tanah yang dikuasai oleh pemerintah daerah menjadi hak pakai dan hak pengelolaan ini, juga ditegaskan dalam Pasal 9 ayat (1) PP No. 24 Tahun

\footnotetext{
$9 \quad$ Ibid., hlm. 256
} 
1997 tentang Pendaftaran Tanah. Dalam PP tersebut dinyatakan bahwa tanah hak pakai dan tanah hak pengelolaan merupakan objek pendaftaran tanah. Hal ini juga ditegaskan dalam Pasal 5 dan Pasal 10 Permen Agraria/ Kepala BPN No. 3 Tahun 1999 tentang Pelimpahan Kewenangan Pemberian dan Pembatalan Keputusan Pemberian Hak Atas Tanah Negara dinyatakan bahwa hak pakai atas tanah negara diberikan dengan keputusan pemberian hak yang diterbitkan oleh Badan Pertanahan Nasional. Hak pakai ini terjadi sejak keputusan pemberian hak didaftarkan kepada Kepala Kantor Pertanahan Kabupaten/Kota setempat untuk dicatat dalam buku tanah dan diterbitkan sertifikat sebagai tanda bukti haknya.

Berdasarkan beberapa aturan tersebut, maka tanah yang dikuasai oleh Pemerintah Daerah Kota Makassar yang belum didaftarkan atau disertifikatkan berakibat pada status hukum tanah tersebut, yakni merupakan Tanah Negara, bahwa status hukum tanah tersebut merupakan tanah negara dan penguasaan yuridisnya ada pada Menteri Keuangan walaupun penguasaan fisiknya ada pada Pemerintah Daerah Kota Makassar. Artinya, Pemerintah Daerah Kota Makassar hanya memiliki kekuasaan untuk menguasai secara fisik tanah tersebut dan menggunakan untuk kegiatan operasionalnya tetapi tidak memiliki kekuasaan yuridis atas tanah tersebut.

Pendaftaran tanah aset yang dilakukan oleh Pemerintah Daerah Kota Makassar, dalam daftar aset tanah yang dikeluarkan Bagian Perlengkapan Sekretariat Kota Makassar April 2012 terdapat 3.711.191 meter persegi yang belum memiliki sertifikat tanah, yang memiliki sertifikat baru 168 aset tanah dengan luas keseluruhan 530.253 meter persegi. Satuan Kerja Perangkat Daerah (SKPD) yang paling banyak memiliki aset tanah belum bersertifikat yakni Dinas Pendidikan sebanyak 262 tanah yang ditempati bangunan sekolah SD, SMP, dan SMA sederajat, tanah yang ditempati 33 Puskesmas dan Rumah Sakit Umum Daerah (RSUD) Daya, dan tanah ditempati Kantor Camat Panakkukang, Rappocini, Mamajang, Biringkanaya, Mariso, Tamalate, Manggala juga belum bersertifikat, dan sekitar 50 kantor Lurah pada 14 kecamatan yang tidak memiliki sertifikat tanah.

Sertifikasi tanah aset daerah juga terjadi pada tanah aset daerah Kota Makassar yang berasal dari tanah bekas milik asing Belanda dan Cina. Hingga saat ini hanya terdapat satu tanah aset daerah bekas tanah milik asing tersebut yang bersertifikat yaitu Museum Kota Makassar (bekas Kantor Walikota Makassar) yang merupakan geementhius pada masa Belanda, Nomor Register Eigendom 323. Luas tanah tersebut adalah $2.238 \mathrm{~m}^{2}$. Tanah ini terletak di Jalan Balaikota Nomor 1, Kelurahan Baru. Tanah tersebut disertifikatkan hak pakai tanggal 16 Juni 1977 Nomor 6714499. Terdapat pula beberapa tanah aset daerah yang telah ditegaskan statusnya oleh Kementerian Keuangan, yakni tanah tersebut telah dihapuskan dari daftar tanah negara agar dapat dimohonkan hak atas tanah oleh Pemerintah Daerah.

\section{Kendala Sertifikasi Tanah Aset Peme- rintah Kota Makassar}

Sertifikasi tanah aset daerah di Kota Makassar termasuk tanah bekas milik asing 
Cina dan Belanda masih sangat rendah walaupun mulai terdapat kemajuan dari sisi jumlah karena telah dilakukannya perubahan mekanisme dalam upaya peningkatan jumlah sertifikasi tanah aset Pemerintah Kota setelah tahun 2012, sertifikasi tanah kepada Satuan Kerja Perangkat Daerah sebagai pengguna barang, sehingga terjadi peningkatan dari 30 bidang tanah aset daerah per tahun yang disertifikatkan oleh Pemerintah Kota Makassar, menjadi 50 bidang tanah per tahun.

Terdapat 2 (dua) kendala dalam pelaksanaan sertifikasi tanah aset daerah: Perta$m a$, Aspek Peraturan Perundang-Undangan; terkait dengan status tanah aset sebagai tanah negara atau barang milik negara dan juga sebagai aset daerah atau barang milik daerah; Ketidakjelasan Status Tanah Ex Gemeente yang Dikuasai Masyarakat; Perlunya Perubahan Peraturan Menteri Keuangan Nomor 154 Tahun 2011 Jo. PMK No. 188 Tahun 2008 tentang Penyelesaian Tanah Bekas Milik Asing/Cina. Kedua, Aspek Administrasi; Kurang Lengkapnya Dokumen yang Berkaitan dengan Tanah Bekas Milik Asing Cina dan Belanda; serta minimnya anggaran penyertifikatan aset berupa tanah yang disediakan oleh APBD.

\section{PENUTUP}

Status hukum tanah aset daerah bekas milik asing Cina dan Belanda di Makassar ada yang masih berstatus tanah negara dan ada juga yang telah berstatus tanah hak. Tanah bekas milik asing Cina dan Belanda yang dikuasai oleh Pemerintah Daerah Kota Makassar, yang telah bersertifikat maupun belum bersertifikat dikategorikan sebagai aset dae- rah. Penyertifikatan tanah termasuk bentuk pengamanan yuridis tanah aset daerah telah dilakukan, namun masih terkendala dari aspek perundang-undangan dan kendala administrasi.

Pemerintah Daerah Kota Makassar seharusnya meningkatkan koordinasi dan menyamakan pemahaman dengan lembagalembaga yang terkait, utamanya Direktorat Jenderal Kekayaan Negara Wilayah XV Makassar dan Badan Pertanahan Nasional. Terkait aspek yuridis, harmonisasi peraturan perundang-undangan yang terkait dengan pengelolaan tanah aset daerah menjadi hal utama yang mesti segera dilakukan. Hal ini penting agar tidak terjadi tumpang-tindih peraturan perundang-undangan dalam pengelolaan tanah aset daerah.

\section{BIBLIOGRAFI}

Arie Sukanti Hutagalung dan Markus Gunawan. (2008). Kewenangan Pemerintah di Bidang Pertanahan. Jakarta: Rajawali Pers.

A.P. Parlindungan. (1993). Komentar Atas Undang-Undang Penataan Ruang. Bandung: Penerbit Mandar Maju.

Kartini Muljadi. (2008). Hak-Hak Atas Tanah. Jakarta: Kencana.

Supriyadi dan Subadi. (2011). "Tanah Aset Daerah dalam Perspektif Konstitusi”. Jurnal Konstitusi, FKKP-Fakultas Hukum Universitas Merdeka Madiun, 1(1): 11-27.

Urip Santoso. (2010). Pendaftaran dan Peralihan Hak Atas Tanah. Jakarta: Kencana Prenada Media Group.

Doli D. Siregar. (2004). Manajemen Aset. Cetakan pertama. Jakarta: PT Gramedia Pustaka Utama.

Supriyadi. (2010). Aspek Hukum Tanah Aset Daerah. Jakarta: PT. Prestasi Pustakaraya. 